\title{
НА МАРГІНЕСІ ДОСЛІДЖЕНЬ ВІЛЕНСЬКОЇ АКАДЕМІЇ, АБО КІЛЬКА СЛІВ ПРО ВІДОБРАЖЕННЯ ПУБЛІЧНИХ ДОКАЗІВ ВМІНЬ, ДІАЛОГІВ І ЕКСПЕРИМЕНТІВ НА ШПАЛЬТАХ «КУРЕРА ПОЛЬСКЕГО»
}

\author{
Б. Манищи
}

\begin{abstract}
Манищ Б. На маргінесі досліджень Віленської академії, або кілька слів про відображення публічних доказів вмінь, діалогів і експериментів на шпальтах «Курсра Польскего». В статті аналізується відображення публічних актів за участі студентів Віленської академії (а саме доказів набутих ними вмінь, театральних вистав, експериментів) на шпальтах першої в Речі Посполитій інформаційної газети («Курєра Польскєго»). 3 одного боку, в фокусі уваги перебуває дидактика і методика навчання, які застосовувалися в межах єзуїтського шкільництва. 3 іншого боку, аналізується феномен пропаганди, яка була покликана посилити позиції Товариства Ісуса у сфері освітньої діяльності, продемонструвати наукову компетентність єзуїтів і знайти нових потенційних благодійників. Загалом в місцевому суспільстві (особливо в середовищі шляхти) прослідковується очевидне зростання інтересу до науки. Це свідчило про наближення змін, які приносить із собою доба Просвітництва.

Ключові слова: Вільно; єзуїти; студенти; наука; шкільництво; театр; вільняни; Головний Трибунал Великого князівства Литовського; докази набутих вмінь; «публічні акти».
\end{abstract}

Маныщ Б. На маргинесе исследований Виленской академии, или несколько слов об отражении публичных доказательств умений, диалогов и экспериментов на страницах «Куриера Польскего». В статье анализируется отражение публичных актов студентов Виленской академии (а именно доказательств приобретенных ими умений, театральных представлений, экспериментов) на страницах первой в Речи Посполитой информационной газеты («Куриера Польскего»). С одной стороны, в фокусе внимания находятся дидактика и методика обучения, которые применялись в рамках иезуитской школьной системы. С другой стороны, анализируется феномен пропаганды, призванной усилить позиции Общества Иисуса в сфере образовательной деятельности, продемонстрировать научную компетентность иезуитов и найти новых потенциальных благотворителей. В целом в местном обществе (особенно в среде шляхты) прослеживается очевидный рост интереса к науке. Это свидетельствовало о приближениях изменений, которые принесет с собой эпоха Просвещения.

Ключевые слова: Вильно; иезуиты; студенты; наука; школьная система; театр; вильняне; Главный Трибунал Великого княжества Литовского; доказательства приобретенных умений; «публичные акты».

Manyś B. On the Margins of the Studying of the Vilno Academy or Some Words about the Reflection of Public Proofs of Skills, Dialogues and Experiments on Columns of "Kurier Polski". The article deals with the reflection of public acts of Vilno Academy's students (namely - of the proofs of the acquired skills, theatrical performances, experiments) on columns of the first informational newspaper in the PolishLithuanian Commonwealth ("Kurier Polski"). On the one hand, it is the vision of the dydaktic methods, which have been used in the Jesuit school system. On the other hand, it is the analysis of the phenomenon of propaganda, which aimed to the strengthening the Jesuits' position in the sphere of school activity, to demonstrate their scientific competence and to find up new potential benefactors. Nevertheless in the local community (especially within szlachta) is evident the increasing interest to science. It marked the incoming of the changes which become obvious in the epoch of Enlightenment.

Keywords: Vilnius; Jesuits; students; science; school system; theatre; Vilnians; Lithuanian Tribunal; the proofs of the acquired knowledge and skills; "public acts".

Будівлі сучасного Віленського університету разом 3 костьолом св. Йоана Хрестителя i св. Йоана Богослова належать нині до найцінніших архітектурних пам'яток литовської столиці, викликаючи захват у туристів, котрі відвідують це місто ${ }^{1}$. У XVIII ст. віленський «науковий і навчальний осередок», створений єзуїтами ще кілька століть тому, був одним 3 провідних в Центрально-Східній Свропі ${ }^{2}$. Своєю чергою місцевий костьол Товариства Iсуса був другою за своєю важливістю католицькою святинею Вільна (після кафедрального собору $)^{3}$. 
Метою даної статті є аналіз відбиття наукової (у широкому розумінні цього слова) діяльності представників Віленської академії на шпальтах першої періодичної газети, що виходила в Речі Посполитій Обох Народів ${ }^{4}$. Треба зауважити, що авторка не ставить перед собою завдання в черговий раз накреслити історію Віленської академії, але прагне лише відповісти на питання: яку інформацію про цей навчальний заклад ${ }^{5}$ (а починаючи 31752 p. - також про Collegium Nobilium ${ }^{6}$ ) подає перша регулярна газета; про які саме наукові заходи писалося на шпальтах преси; наскільки академічний простір використовувався для проведення теологічних диспутів, а наскільки - для доказів оволодіння різними вміннями; кому вони присвячувалися і чи були доступні для ширшої громадськості; нарешті, в якій мірі залишалися «продуктом», доступним лише для духовних осіб. Важливим $є$ також окреслити, наскільки костел св. Йанів (тобто місце, присвячене служінню Богові) використовувалося єзуїтами для презентації і пізнання - не тільки священиками, але також мешканцями столиці Литви - взаємовідносин людина-Бог ${ }^{7}$.

Слід зауважити, що нинішня наша праця не претендує на те, аби повністю розкрити запропоновану проблематику. Вона лише слугує доповненням до більш глибоких досліджень наукової діяльності єзуїтів і тих дидактичних методів, що застосовувалися в їх шкільництві. Водночас варто підкреслити, що ця розвідка хронологічно обмежується сорока роками XVIII ст. Необхідно також наголосити на тому, що ми свідомо оминаємо своєю увагою діяльність єзуїтської друкарні, котра - 3 огляду на великий обсяг відповідної інформації на шпальтах газети - складає окрему тему дослідження, опрацювання якої може розширити існуючі досі знання 8 .

Вищезгадане обмеження хронологічних рамок дослідження зумовлюється використанням певного кола джерел. Нинішня наша розвідка спирається на прес-релізи, розміщені на шпальтах «Курєра Польскєго» - першої періодичної газети інформаційного характеру, що виходила друком в 1729-1733 і 1737-1760 рр. Цей щотижневик досить детально досліджений в історіографії9. Додаткову інформацію ми почерпнули зі стародруків XVIII ст., а також $з$ опрацьованого в рамках даного дослідницького проекту діаріушу віленського храму $^{10}$. Слід також пам'ятати, що «Курєр Польскі» публікувався єзуїтами, а тому наявні на його шпальтах відомості мали значною мірою пропагандистський характер. Останне, втім, не спростовує того факту, що наявна в цьому виданні інформація дозволяє (принаймні частково) змалювати наукову діяльність представників Віленської академії. А також (і це здається особливо цінним) окреслити її суспільний контекст. Іншими словами, унаочнити не лише те, що презентувалося, але й ким, для кого і за яких обставин.

У «Курєрі Польскому» нам вдалося знайти одинадцять повідомлень, котрі можна вважати доказом «наукової» діяльності представників Віленської академії. В нинішній розвідці враховано лише ті записи, які стосуються конкретних заходів наукового характеру, що відбувалися у стінах Академії, костьолі Св. Йоанів або в Collegium Nobilium. Водночас проігноровано згадки про участь і залучення представників Віленської академії (шляхом виголошення проповідей, промов або присвячення панегірику) до різних урочистостей 3 певної нагоди (йдеться про поховання державного чи церковного достойника, вступ на посаду, інгрес, принагідні візити, заручини або також іменини $)^{11}$. Згідно 3 окресленими вище критеріями можна стверджувати, що в «Курєрі Польскому» друкувалися звіти про: «демонстрації», експерименти, діалоги і «публічні акти». На сторінках цієї нашої статті аналізуються лише окремі повідомлення, що стосуються наукового поступу.

Варто зауважити, що у повідомленні з Вільна, опублікованому в номері «Курєра Польского» за 22 жовтня 1755 р., зазначалося: "Місцева академія, аби підтримувати дисципліну серед панів студентів і сприяти їх сильнішому поступу у навчанні, постановила, аби за прикладом інших академій - пани студенти вищих класів демонстрували набуті ними вміння, складаючи публічні іспити. А ті, які відмовляться слідувати цьому правилу або ж не досягнуть значних успіхів в освоєнні наук, нехай будуть усунуті з Академії, аби не посідали місце інших паничів - більш підходящих до навчання і нагляду за ними [...]"12. Поява цієї досить серйозної постанови, яка мала характер публічної інформації, що доносилася владою Академії до відома громадськості, ймовірно була зумовлена бажанням систематизувати вищезгадані виступи або ж слугувала пересторогою для майбутніх вихованців. Якщо визнати ці чинники визначальними, тоді можна припустити, що частина студентів Академії таки виступала проти публічної презентації своїх здобутків. 
На підставі аналізу джерел можна зробити висновок, що більшість таких заходів хронологічно вписується у віленську каденцію засідань Головного Трибуналу Великого князівства Литовського, а отже - збігається у часі із перебуванням у місті маршалків і депутатів відповідних сесій. 3 одного боку, подібна синхронність зумовлювалася тим, що демонстрація вмінь (тобто - «публічні акти») була однією з численних форм дозвілля для шляхти, що перебувала у місті ${ }^{13}$. Відомо, що в низці випадків участь Академії в таких заходах ініціювалася саме маршалками. Власне так сталося 1749 року. У звіті, опублікованому 9 серпня того року, зазначається, що о другій годині пополудні в єзуїтському костелі св. Йоанів відбулася найпочесніша церемонія у царині вільних мистецтв і філософії (йдеться про акт присудження ступеню бакалавра), якій передував публічний філософський диспут ${ }^{14}$. Відомо також, що цей акт присвячувався Юзефу [Сжи] Гильзену, синові каштеляна інфлянтського Яна Августа з Еклів Гильзена ${ }^{15}$, маршалка Головного Трибуналу Великого князівства Литовського. Останній “[...] особисто разом з усім Трибуналом був присутній на цьому акті [...]"16. Варто додати, що 13-річному Гильзену вихованці Віленської академії 3 серпня 1749 р. присвятили книжку Aristoteles, sub fortunatissimis auspiciis [...](«Аристотель, під найщасливішим верховенством» [...] $)^{17}$. Йоанна Ожел, Арвидас Пацевічюс і Станіслав Рошак встановили, що віленські алюмни подарували працю 3 царини метафізики і етики ${ }^{18}$. Слід зазначити, що вона стосувалася наступних дисциплін: Assertiones ex Aristotelis Philosophia (тверджень з філософії Аристотеля), Ex logica (з логіки), Physica (з фізики), Ex libris de mundo et coelo (з книг про світ і небо), De elementis (про елементи), De meteoris sive mixtis (про метеор або мішанину), Ex metaphysica (з метафізики). Наприкінці вказувалися особи, котрі здобули ступінь бакалавра ${ }^{19}$. На цьому публічному акті були присутні не тільки депутати Трибуналу, але й духовні особи.

На шпальтах «Курєру Польского» згадується Александер Казимир Гораїн - єпископсуффраган жмудський ${ }^{20}$ і Юзеф Домінік Пузина - єпископ-суффраган інфлянтський ${ }^{21}$, а також "[...] багато різних їх милостей distinctioris ordinis ${ }^{22}$, численні присутні Cleri tam Saecularis quam Regularis ${ }^{23}$ і різні їх милості notabili copia ${ }^{24,25}$. Втім постає питання, чому не було згадано єпископа віленського Міхала Яна Зєнковіча ${ }^{26}$ і єпископа-коад’ютора віленського Юзефа Станіслава Сапєгу ${ }^{27}$. Вищезгадану подію можна вважати специфічною. Адже вона відбулася у стінах святині, яка хоча й підпорядковувалася єзуїтам, але виконувала функцію парафіяльного костелу. Таким чином Академія немов би долучалася до місцевої громадськості, роблячи це в особливий день - королівських іменин, які у Вільно мали характер національного свята ${ }^{28}$. Варто додати, що демонстрація набутих вмінь, вистави і навіть феєрверки для міщан щорічно влаштовувалися у столиці Литви на День св. Катерини - патронки науки ${ }^{29}$.

В 1756 р. у Віленській академії демонструвалися «публічні докази вміння вимірювати грунти» ${ }^{30}$. Як було зауважено на сторінках «Курєра Польского», ці «докази» презентувалися у присутності Єжи Флеммінга, маршалка Головного Трибуналу Великого князівства Литовського ${ }^{31}$ i “всіх їх милостей панів суддів і багатьох інших високоповажних гостей”32. На підставі звіту, надрукованого в газеті, можна зробити висновок, що того дня роздавали theses mathematicae ${ }^{33}$, “присвячені найсвятішому Трибуналові"34. Відомо також, що по завершенні цього «публічного доказу» у присутності зібраних гостей відбулася дискусія за участі оо. піярів. Як відомо, між віленськими єзуїтами і піярами існували напружені відносини. Їх причиною була суперечка щодо права на «монополію» в шкільній діяльності (1723-1753 рр. $)^{35}$. Такі дискусії мали не лише наукове підгрунтя. Вони слугували продовженням «війни» між двома орденами, метою якої було довести «наукову» i «дидактичну» перевагу одних над іншими та переконати присутню у місті шляхту у слушності своєї позиції. А отже - заручитися їх протекцією і здобути фінансову підтримку. Важко стверджувати, наскільки ця дискусія або полеміка була заздалегідь запланованою, а наскільки - неочікуваною для організаторів. Наявний джерельний матеріал не дозволяє дати відповідь на подібне питання.

У деяких ситуаціях замість «актів», які підтверджували опанування точних наук, студенти демонстрували акторські вміння, граючи в трагедії чи комедії ${ }^{36}$. I це аж ніяк не дивувало читача, оскільки, як відомо, славу орденові приніс в т.ч. шкільний театр. Сзуїти вважали його дієвим дидактично-освітнім знаряддям, яке щодо студентів відігравало ви- 
ховну функцію, а стосовно міської спільноти - важливу пропагандистську роль ${ }^{37}$. У серпні 1754 р. в залі Віленської академії було зіграно трагедію «Свобода й авторитет костелів і священиків або Євтропій» («Wolność i powaga kościołów i duchownych, albo Eutropiusz») Цю виставу, як зазначається в «Курєрі Польскому», презентували “від імені” Константи Людвіка Плятера ${ }^{39}$ (тодішнього маршалка Головного Трибунала Великого князівства Литовського ${ }^{40}$, полоцького каштеляна) i його дружини Августи Плятер з роду Огінських ${ }^{41}$. На жаль у газетному звіті бракує інформації про те, у зв'язку із чим було зіграно цю трагедію. Можна припустити, що таких мотивів було принаймні три. По-перше, йдеться про надання Плятеру полоцької каштелянії, яку той отримав 14 липня $1754 \mathrm{p}^{42}$. Залучення Академії і постановка трагедії мали, звісно, лише підкреслити кар'єрне зростання Константи Людвіка. Слід пам'ятати, що це був ідеальний час для проведення подібних заходів. У місті перебували депутати Трибуналу і шляхта з навколишніх земель, котрі з'їхалися, аби взяти участь у святкуванні королівських іменин. Останні можна вважати другим мотивом. А третім - обрання того ж року Плятера маршалком Головного Трибуналу, який зазвичай й ставав фундатором урочистостей, котрі проводилися у Вільні з нагоди королівських іменин $^{43}$. Отже, постановка цієї трагедії представниками Віленської академії мала, з одного боку, підкреслити статус Плятера, а з іншого - провістити наближення святкового часу ${ }^{44}$.

Кількома місяцями раніше (у травні того ж року) кавалери єзуїтського Collegium Nobilium поставили в академічному залі французьку комедію «Тімон Мізантроп» («Timon le Misanthrope» $)^{45}$, автором якої був Луї-Франсуа Делісль де ля Древет'єр. Серед іiї глядачів були присутні у місті сенатори, міністри, урядовці і гості, які прибули до Вільна на заручини "Галкі, ошмянського гродського писаря з її милістю панною Анною Войнянкою, дочкою старости дзісненського" 4 .

«Докази» $\mathrm{i}$ «демонстрації» вмінь також часом присвячувалися найвищим церковним $\mathrm{i}$ державним сановникам. Але вони завжди відбувалися у присутності депутатів Головного Трибуналу Великого князівства Литовського. Такі посвяти мали характер подяки. Студенти Віленської академії від імені керівництва своєї Almae Matris дякували та висловлювали вдячність і відданість за підтримку - як фінансову, так і матеріальну. Звіти у пресі - це інколи єдине джерело, на підставі якого ми можемо дізнатися, як проходили й оформлювалися ті урочистості. Слід однак пам'ятати, що подібні реляції носять однобічний характер. Ймовірно їх писали єзуїти (у попередній історіографії так і не вдалося встановити, ким були особи, чиї донесення вміщено на шпальтах газети), головним «редакторським» завданням яких було створити певний образ Академії. Це однак не змінює того факту, що наукові заходи, котрі розглядаються в нинішній статті, набували форми театральних видовищ, в яких можна побачити акторів, глядацький зал, сцену і навіть сценарій. Отже, перебуваючи у місті, шляхта мала справу зі спектаклем, який був засобом/формою пошанування донаторів і протекторів. 3 іншого боку, для єзуїтів, котрі керували Академією чи Collegium Nobilium, такі випадки були шансом продемонструвати свої досягнення, наголосити на успіхах, або одним зі способів впливу на віленську спільноту.

Деякі з подібних заходів обмежувалися лише науковою складовою. Саме такий характер мали два «публічні акти», влаштовані наприкінці липня 1754 р. в академічній аулі Віленського університету. Перший із них відбувся 22 липня, був пов'язаний із математикою ${ }^{47}$ і присвячений Юзефові Станіславу Сапєзі ${ }^{48}$, єпископу-коад’ютору віленському ${ }^{49}$. Причини саме такого вибору на шпальтах преси ніяк не пояснювалися. Можемо лише здогадуватися, що він зумовлювався тим, що роком раніше вищезгаданий єпископ подарував телескоп астрономічній обсерваторії Академії ${ }^{50}$. Не можна виключати й того, що «публічний акт» було продемонстровано на честь вісімнадцятої річниці від того моменту, коли Август III номінував Сапєгу на коад'юторство у віленському єпископстві ${ }^{51}$. Тези, які презентувалися у присутності духовних осіб (в т.ч. прелатів та каноніків), депутатів Головного Трибуналу Великого князівства Литовського і різних професорів, стосувалися теоретичної і сферичної тригонометрії ${ }^{52}$, а також механіки. Другий акт відбувся трьома днями пізніше. Постулати, представлені Котовічем - вихованцем Віленської академії - мали відношення до арифметики і геометрії. Так само, як і в інших випадках, було заплановано дискусію, в якій взяли участь студенти і запрошені гості ${ }^{53}$.

Цілком інакше виглядає «experyment rocznej aplikacyi z różnych scencyi», який в 1753 р. представили кавалери Collegium Nobilium ${ }^{54}$. Шляхетські сини продемонструва- 
ли свої здобутки у царині релігії, універсальної і хронологічної історії. Потім доводили вміння в сфері математики і презентували “різні цікаві питання" з астрономії і географії (в т.ч. - «регіональної»). В рамках останньої вони характеризували найзначніші держави, акцентуючи увагу на успіхах правлячих у них династій. Програма виступу природно також передбачала презентацію основ спорудження фортифікацій і засад їх побудови згідно із методом маршала де Вобана ${ }^{55}$. Цю проблематику розглядали згідно із системою, розробленою і представленою в трактаті двох прусських шляхтичів - Генріха і Йоганна де Маттушків (він вийшов друком в 1750 р. у Вроцлаві) ${ }^{56}$. Все це студенти презентували трьома мовами (польською, французькою і латиною), доводячи, що вони набули вміння користуватися двома останніми ${ }^{57}$. Французька мова у XVIII ст. вважалася засобом комунікації вищих суспільних верств і водночас - мовою культури Просвітництва. А тому кожен більш-менш заможний шляхтич був зобов'язаний володіти нею хоча б на рівні усного мовлення ${ }^{58}$. Своєю чергою латина була мовою науки. А тому кожен публічний акт або доказ набутих вмінь ставав водночас свідченням оволодіння мистецтвом риторики, наявності вірної вимови, тренуванням пам'яті й спробою засвоєння граматичних норм ${ }^{59}$. Як зауважено в «Курєрі Польскому», кавалери, “надаючи докази своїх вмінь, розважали зацікавленого глядача" ${ }^{\circ} .3$ газетного звіту стає зрозумілим, що наукові «експерименти» презентувалися 3 “доброю манерою”. Глядачам також пропонувалися французькі танці, фехтування і стрільба в щит ${ }^{61}$.

Як вже зауважувалося, представники Академії також презентували свої вміння у присутності державних високопосадовців. Так сталося у травні 1753 р., коли цей навчальний заклад відвідав Міхал Казимир Радзивил «Рибонька» ${ }^{62}$ - великий гетьман литовський і воєвода віленський ${ }^{63}$. Він, подібно до інших можновладців, приїхав до Вільна у зв'язку iз реасумпцією справ Головним Трибуналом Великого князівства Литовського ${ }^{64}$. Перед тим, як залишити місто, цей високопосадовець разом із сином - Каролем Станіславом на прізвисько «Пане Коханку», мечником великим литовським ${ }^{65}$ - й іншими достойниками відвідав математичний «музей» Академії, в якому вони із захватом спостерігали численні, розмаїті й цікаві експеременти. 3 преси можна дізнатися, що високим гостям пропонувалися "[...] один за одним нещодавно винайдені [...] ефекти електризації [...]"66. Окрім того, вони побачили “досить цікаві physicae experimentalis"67, під час яких за допомоги “великої сили" випарювалася вода і здійснювалися інші effectus ${ }^{68}$, які походили ex principiis dioptricis, catoptricis, hydrostaticis ${ }^{69}$. Наприкінці свого візиту до Академії Міхал Казимир Радзивил "Побачивши praeparatoria70 до нового відкриття observatorii astronomii $^{71}$, подарував facultati mathematicae ${ }^{72}$ цінний thelescopium gregorianum ${ }^{73}$ і пообіцяв інші raritates" $" 74$.

3 газетних звітів дізнаємося про те, що демонстрація в стінах Академії експериментів, пов’язаних із “електризацією”, відбувалася в т.ч. у присутності дам. Значна увага до них 3 боку жінок можливо зумовлювалася тим, що обсерваторію відкрили 1753 р. завдяки фундації Ельжбети Пузини з роду Огінських ${ }^{75}$, дружини мстиславського каштеляна. Вона була не лише щедрою меценаткою єзуїтів, але й послідовною покровителькою точних наук ${ }^{76}$. Аби показувати різні досліди (в т.ч. й ті, котрі здійснювалися у колегіумі), в академічному залі було розміщено меншу electrica машину та «інструменти», необхідні для проведення досліджень в сфері математики і експериментальної фізики. Демонстрація для дам відбулася 16 травня. Варто додати, що серед глядачів були Бальбіна Пац ${ }^{77}$, дружина каштеляна жмудського; Анна Хрептович ${ }^{78}$, дружина каштеляна брестського, 3 дочкою Маріанною ${ }^{79}$; Анна Тишкевич ${ }^{80}$, дружина тивуна віленського; Регіна Хрептович ${ }^{81}$, дружина старости вербельського і чимало інших ${ }^{82}$. Більшість із них були так чи інакше пов'язані 3 цим єзуїтським навчальним закладом, надаючи йому фундації або ж маючи чоловіків, які здобували освіту в Академії (зокрема, йдеться про Хрептовича).

Таким чином, на шпальтах «Курєра Польского» міститься інформація, яка засвідчує наукову і дидактичну діяльність єзуїтів в столиці Великого князівства Литовського. Аналіз джерел доводить, що найбільше звітів про презентаційні заходи можна знайти в номерах газети за кінець $1740-\mathrm{x}$ - першу половину 1750 -х рр. Можливо, подібний стан речей був наслідком чи результатом дедалі зростаючого конфлікту між піярами і єзуїтами, який остаточно завершився в 1753 р. Адже тижневик був досить важливим пропагандистським знаряддям в руках Товариства Ісуса. Організація численних «публічних актів» і демонстрація 
«доказів» набутих вмінь починаючи з 1755 р. стали обов'язковим елементом «дидактики» в рамках єзуїтського шкільництва. Всі наукові заходи, організовані членами Товариства Ісуса та їхніми учнями, мали характер театральних видовищ, в яких можна вирізнити акторів (представників Академії), публіку (депутатів Головного Трибуналу Великого князівства Литовського і міську спільноту) та сценарій. Останній включав демонстрацію вмінь в царині математики (i, насамперед, арифметики) або механіки. Чимало уваги приділялося також історії та філософії. Варто підкреслити, що більшість подібних актів мала свого персоніфікованого адресата. Ним був маршалок Головного Трибуналу або хтось 3 присутніх у місті державних чи церковних достойників. Публічна демонстрація студентами своїх знань і вмінь була покликана зміцнити позиції єзуїтів на полі шкільництва, довести їх наукову компетентність, а насамперед - здобути нових фундаторів і донаторів. Слід також звернути увагу на те, що вочевидь існував «суспільний запит» на демонстрацію наукових новинок і цікавинок. Подібні заходи стали «модними» і користувалися великою популярністю. То провіщало прийдешню зміну, яку принесло із собою Просвітництво.

\section{(Переклад з польської Сергія Сєрякова)}

${ }^{1}$ Сжи Пашенда так охарактеризував комплекс будівель Віленської академії: “[...] це найбільший архітектурний ансамбль світських будівель, який поєднує у собі елементи всіх стилів, від готики до неокласицизму [...] Університетський ансамбль віддзеркалює майже всю історію віленської столиці і справедливо може вважатися символом давньої слави Вільна". Див.: Paszenda J. Budowle jezuickie w Polsce XVI-XVIII w. T. 1. Kraków, 1999. S. 403. Детальну бібліографію різних аспектів функціонування і діяльності Віленської академії див.: Wilno // Encyklopedia wiedzy o jezuitach na ziemiach Polski i Litwy [далі-EWOJ] / oprac. L. Grzebień. Kraków, 2004. S. 743. Спорудження і архітектура костелу розглядається в праці В. Дреми. В ній також подається бібліографія: Drema V. Vilniaus Sv. Jono bažnyčia. Vilnius, 1997. Варто переглянути також такі праці: Jaloveckas R., Dambrauskaite T., Buvusios Sv. Jono bažnyčios Vilniuje restauraciniai darbai (tęsinys) // Architektūros paminklai. T. I-II. Vilnius, 1970-1972; Čaplinskas A. R. Vilniaus gatvių istorija. Šv. Jono, Dominikonų, Trakų gatvès. Vilnius, 1996. S. 50-59. Про костел св. Йоанів див.: Kraszewski J. I. Wilno od początków jego do roku 1750. T. 2. Wilno, 1840. S. 436-445; Zahorski W. Przewodnik po Wilnie. Wyd. 2. Wilno, 1921. S. 176; Kaczorowski B. Zabytki starego Wilna. Warszawa, 1991. S. 72-83; Bohdziewicz P. O dwu kościołach gotyckich św. Jana w Wilnie // Roczniki Humanistyczne. T. 13 (1965). Z. 4. S. 5-14; Paszenda J. Kościół Sw. Jana w Wilnie w okresie jezuickim 1571-1773 // Kwartalnik Architektury i Urbanistyki. T. 30 (1985). Z. 3. S. 265-279; Ejusdem. Sztuki wileńskie XVIII wieku w świetle archiwów jezuickich // Biuletyn Historii Sztuki. T. 36 (1974). S. 158-168.

${ }^{2}$ Станіслав Обірек так написав про Віленську академію та костел св. Йоанів: “[_...] це рідкісний приклад адаптації існуючого готичного костелу до нових пастирських цілей, впродовж всього періоду перебування єзуїтів у Вільно тривала розбудова комплексу Віленської академії - потужного осередку західної культури, промені якого пронизували не лише всю Литву, але й сусідні країни Східної Свропи". Див.: Obirek S. Czy istniał styl jezuicki. Recenzja na: Paszenda Jerzy. Budowle jezuickie w Polsce XVI-XVIII w. T. 1-4. Kraków, 1999-2010 // Res Historica. T. 32 (2011). S. 167.

${ }^{3}$ Його статус зумовлювався тими функціями, котрі були покладені на нього - спочатку в якості парафіяльного костелу (в XV ст.), а згодом - храму Академії (в другій половині XVI ст.). Див.: Kraszewski J. I. Wilno od początków jego do roku $1750 \ldots$... S. 418.

${ }^{4}$ Grzebień L. Dotychczasowa literatura o wkładzie jezuitów do nauki i kultury // Wkład jezuitów do nauki i kultury w Rzeczypospolitej Obojga Narodów i pod zaborami / red. I. Stasiewicz-Jasiukowa. Kraków, 2004. S. 5-32.

${ }^{5}$ Король Стефан Баторій 7 липня 1578 р. видав у Львові ерекційний акт Академії, а 1 квітня 1579 р. підписав у Вільно формальний диплом у тій справі. Він також затвердив фундаційний акт, складений у серпні 1578 р. віленським єпископом Валеріаном Проташевичем. 30 жовтня 1579 р. папа Григорій XIII затвердив привілей Стефана Баторія. Див.: Piechnik L. Początki Akademii Wileńskiej 1570-1599. Rzym, 1984. S. 56-58; Puchowski K. Jezuickie kolegia szlacheckie. Studium z dziejów edukacji elit. Gdańsk, 2007. Див. також: Przywilej króla Stefana (Batorego) dany Jezuitom kolegium wileńskiego we Lwowie, 7 lipca roku 1578, na ustanowienie Akademii w Wilnie, [...] // Baliński M. Dawna Akademia Wileńska. Próba jej historii od założenia w roku 1579 do ostatecznego jej przekształcenia w roku 1803. Petersburg, 1862. Nr I. S. 415-416; Akt fundacyi i uposażenia Akademii wileńskiej, [...] // Ibidem. Nr II. S. 417-426; Bulla Grzegorza XIII Najwyższego Pasterza// Ibidem. Nr III. S. 427-434; Przywilej króla Stefana na Akademię wileńską, dany w Wilnie, dnia 1 kwietnia r. 1579, z zachowaniem form legalnych // Ibidem. Nr IV. S. 435-438. 
${ }^{6}$ Спочатку завдяки фундації Даніеля Шишки створюється шляхетський конвікт (1737 р.), який згодом було перетворено на шляхетський колегіум. Див.: EWOJ. S. 292, 741.

${ }^{7}$ Przybylska L. Pojęcie przestrzeni sakralnej // Geografia i sacrum / red. B. Domański, S. Skiba. Kraków, 2005. S. 381-387.

${ }^{8}$ Про історію друкарні Віленської академії (1575-1773 рр.) див.: Petrauskiene I. Vilniaus Akademijos spaustuvè 1575-1773. Vilnius, 1976.

${ }^{9}$ Eojek J. Prasa polska w latach 1661-1831 // Prasa polska w latach 1661-1864 / red. J. Łojek. Warszawa, 1976. S. 18-24. Див. також: Hombek D. Prasa i czasopisma polskie XVIII wieku w perspektywie bibliologicznej. Kraków, 2011. S. 49-57. В процесі підготовки нинішньої статті нами було використано номери «Курєра Польскєго», які зберігаються в Бібліотеці Ягеллонській. Див.: BJ. St. Dr. 235 II czasop.

${ }^{10}$ Lietuvos valstybės istorijos archyvas (далі - LVIA). Fond 1135. Op. 20. Sygn. 302. Дослідницький проект «Dwa XVIII-wieczne diariusze wileńskiego kościoła p.w. św. Janów w Wilnie - opracowanie i edycja źródłowa». NCN. Nr projektu UMO-2014/13/D/HS3/03706.

${ }^{11}$ Наприклад, зі звіту, оприлюдненого 14 квітня 1744 р., дізнаємося, що 23 березня (тобто - в день св. Георгія) студенти Віленської академії запросили маршалка Головного Трибуналу Великого князівства Литовського Сжи Радзивила до костелу св. Йоанів, в якому о. Адам Абрамовіч (EWOJ. S. 1) “[...] під час виголошення disertissimo ore привітав Князя Маршалка з іменинами [...]. Місцева Академія, зусиллями того ж його милості префекта о. Абрамовіча і їх милостей панів студентів, привітала патрона його милості князя [...]”. Див.: Kurier Polski (далі - KP). 1744. Nr 377. Z Wilna. 14.IV.1744. Так само див.: KP 1745. Nr 455. Z Wilna. 10.VIII.1745. Про Сжи Радзивила див. детальніше: Dymnicka-Wołoszyńska H. Radziwiłł Jerzy (1721-1754) // Polski słownik biograficzny (далі - PSB). T. 30. Wrocław, 1987. S. 237-238. Див. також: Deputaci Trybunału Głównego Wielkiego Księstwa Litewskiego (1697-1794). Spisy (далі-Deputaci) / red. A. Rachuba. Warszawa, 2004. S. 199.

${ }^{12}$ KP. 1755. Nr 120. Z Wilna. 22.X.1755.

13 Див. також: Gombin K. Trybunał Koronny. Ceremoniał i sztuka. Lublin, 2013. S. 48-52. Ha сторінках номеру 726 «Курєру Польского» за 1750 р. читаємо, що в суботу 1 серпня у єзуїтів демонструвався діалог, який "молодь" Віленської академії склала "красивою симетрією". [На цьому заході] був присутнім “весь” Трибунал “з метою цікавого перегляду”. 3 серпня, в понеділок, відзначали королівські іменини. Див.: KP 1750. Nr 726. Z Wilna. 6.VIII.1750.

${ }^{14}$ Praevia disputatione publica ex universa Philosophia (лат.) - [йому] передував публічний диспут із всього курсу філософії.

${ }^{15}$ Deputaci... S. 220.

${ }^{16}$ KP 1749. Nr 674. Z Wilna. 9.VIII.1749.

${ }^{17}$ Aristoteles, sub fortunatissimis auspiciis, [...], Domini Josephi de Ekliis Hylzen praefecti margenhausensis, [...], Mecaenatis amplissimi. In Alma Academia et universitate vilnensi pro suprema AA. LL. et philosophiae laurea decertans, [...]. Vilnae, [1749].

${ }_{18}$ Orzeł J., Pacevičius A., Roszak S. Diariusz Józefa Jerzego Hylzena na tle pamiętników XVIII stulecia // Dziennik podróży Józefa Jerzego Hylzena z lat 1752-1754 / sud. A. Pacevičius, parengė J. Orzeł, A. Pacevičius, S. Roszak. Vilnius, 2013. S. 40.

${ }^{19}$ Ванковіч, Матеуш Сагайло, Юзеф Нєвяровіч, Кароль Гедімін, Матеуш Пшеходський і Анджей Лєоновіч.

${ }^{20}$ Kościół zamkowy czyli katedra wileńska w jej dziejowym, liturgicznym, architektonicznym i ekonomicznym rozwoju. Na podstawie aktów kapitulnych i dokumentów historycznych / oprac. J. Kurczewski. Wilno, 1908. S. 326.

${ }^{21}$ Szklarska E. Puzyna Józef (zm. 1752) // PSB. T. 29. Wrocław, 1986. S. 491-492.

${ }^{22}$ Distinctioris ordinis (лат.) - вищого стану.

${ }^{23}$ Cleri tam Saecularis quam Regularis (лат.) - представники як світського, так і чернечого кліру.

${ }^{24}$ Notabili copia (лат.) - знамениті особи у великій кількості.

${ }^{25}$ KP 1749. Nr 674. Z Wilna. 9.VIII.1749. Див. також: Wileńskie aniwersarze imienin Augusta III w świetle prasy informacyjnej z epoki / oprac. B. Manyś. Poznań, 2016. S. 93-95.

${ }^{26}$ Він був єпископом віленським в 1730-1761 pр. Див.: Przyałgowski W. Żywoty Biskupów wileńskich. T. 3. Petersburg, 1860. S. 133-168.

${ }^{27}$ Zielińska Z. Sapieha Józef Stanisław (1708-1754) // PSB. T. 35. Warszawa-Kraków, 1994. S. $24-27$.

${ }^{28}$ Wileńskie aniwersarze... S. 67-69.

29 Детальніше про це див.: KP 1740. Nr 209. Z Wilna. 27.XI.1740; KP 1741. Nr 262. Z Wilna. 1.XII.1741. Див. також: LVIA. Fond 1135. Op. 20. Sygn. 302. K. 99-101v.

${ }^{30} \mathrm{KP}$ 1756. Nr 159. Z Wilna. 26.VII.1756.

${ }^{31}$ Konopczyński $W$. Flemming Jan Jerzy Detlov (1699-1771) // PSB. T. 7. S. 35-36; Deputaci... S. 246-247.

${ }^{32} \mathrm{KP} 1756 . \mathrm{Nr} 159 . \mathrm{Z}$ Wilna. 26.VII.1756.

${ }_{33}$ Theses mathematicae (лат.) - математичні тези, твердження.

${ }^{34}$ KP 1756. Nr 159. Z Wilna. 26.VII.1756. 
${ }^{35}$ Конфлікт між єзуїтами і піярами змальовує, зокрема, Юзеф Ігнаци Крашевський: Kraszewski J. I. Wilno od początków jego do roku 1750. S. 475-484. Див. також: Wiadomość o sporze pijarów wileńskich z jezuitami wileńskimi (r. 1723 - 1753) // Moszyński A. Żywot Macieja Dogiela z przydaniem wiadomości o sporze pijarów wileńskich z jezuitami wileńskimi (roku 1723-1753). Wilno, 1838. S. 66-67; Szulc W. Spory Akademij Wileńskiej z Pijarami o wyłączne prawo na szkoły 1723-1753 // Ateneum Wileńskie. R. 14 (1939). Z. 1. S. 70-144.

${ }^{36} \mathrm{KP}$ 1754. Nr 56. Z Wilna. 7.VIII.1754.

37 Детальніше про засади діяльності єзуїтського театру див.: Sprutta J. Z dziejów szkolnego teatru jezuickiego na ziemiach polskich w XVI-XVIII wieku // Nauczyciel i Szkoła. 2012. Nr 2. S. 57-77. Taм також можна знайти базову літературу з цього питання. Окрім того, див.: Alexandrowiczowa M. Dzieje teatru wileńskiego. Odbitka z tomu 2 wydawnictwa "Wilno i ziemia wileńska". Wilno, 1938. S. 2 -4.

${ }^{38}$ Estreicher K. Bibliografia polska. Stólecie XVIII. T. 9. Kraków, 1888. S. 264.

${ }^{39}$ Zielińska Z. Plater Konstanty Ludwik (1722-1778) // PSB. T. 26. Wrocław, 1981. S. 672-674.

${ }^{40}$ Deputaci... S. 238.

41 Ї̈̈ шлюб із Плятером було укладено в 1744 р. Див.: Zielińska Z. Plater Konstanty Ludwik (17221778)... S. 672

${ }_{42}$ Zielińska Z. Plater Konstanty Ludwik (1722-1778)... S. 672.

${ }^{43}$ Wileńskie aniwersarze... S. 22-24.

${ }^{44}$ Пор.: KP 1750. Nr 726. Z Wilna. 6.VIII.1750.

${ }^{45}$ Timon le Misanthrope, comédie en trois actes, précédée d’un prologue. Par le sieur D***. Vienne, 1753. В цьому творі розповідається про афінського громадянина, легендарного мізантропа.

${ }^{46} \mathrm{KP} 1754 . \mathrm{Nr} 45 . \mathrm{Z}$ Wilna. 13.V.1754.

${ }^{47} \mathrm{KP} 1754 . \mathrm{Nr} 55 . \mathrm{Z}$ Wilna. 29.VII.1754.

${ }^{48}$ Zielińska Z. Sapieha Józef Stanisław (1708-1754)... S. 24-27.

49 Він був єпископом-коад'ютором в 1736-1754 pp.

${ }^{50}$ Zielińska Z. Sapieha Józef Stanisław (1708-1754)... S. 26. S. 24.

${ }^{51}$ Його було номіновано 4 липня 1736 р. Див.: Zielińska Z. Sapieha Józef Stanisław (1708-1754)...

52 Вивчає зв'язки між сторонами і кутами сферичних трикутників. В них сторонами $\epsilon$ дуги великих кіл, які є меншими за півкола. Головними дослідниками сферичної тригонометрії вважаються Менелай Александрійський і Клавдій Птолемей.

${ }^{53}$ KP 1754. Nr 55. Z Wilna. 29.VII.1754.

${ }^{54}$ KP 1753. Nr 878. Z Wilna. 30.VI.1753.

${ }^{55}$ Себаст'єн ле Претр, маркіз де Вобан (1633-1707 рр.). Див.: Le Bouyer (ou Le Bovier) de Fontenelle $B$. Éloge de M. le maréchal de Vauban, dans Histoire de l'Académie royale des sciences. Année 1707. Paris, 1730. S. 165-175; Virol M. Vauban: De la gloire du roi au service de l’État. Seyssel, 2003.

56 Traité de L`art. militaire dans la fortification L`attaque et la defense des places selon la methode de monsieur le Marechal de Vauban par ms. les comtes Henri de Mattuschka et Jean de Mattuschka [...]. Breslau, 1750.

${ }^{57}$ Пор.: KP 1759. Nr 13. Z Wilna. 20.III.1759.

58 Про роль французької мови див.: Bochnakowa A. Język francuski w I Rzeczypospolitej // Polszczyzna i inne języki. Materiały z seminarium naukowego poświęconego pamięci doc. dr hab. Józefa Reczka / red. A. Bochnakowa, L. Bednarczuk, J. Waniakowa. Kraków, 2009. S. 30-34.

${ }^{59}$ Poplatek J. Studia z dziejów jezuickiego teatru szkolnego w Polsce. Wrocław, 1957. S. 22.

${ }^{60} \mathrm{KP} 1753$. Nr 878. Z Wilna. 30.VI.1753.

${ }^{61}$ Ibidem.

62 Він був номінований великим гетьманом і воєводою віленським 5 жовтня 1744 р. Див.: Urzędnicy centralni i dygnitarze Wielkiego Księstwa Litewskiego XIV-XVIII wieku. Spisy (далі - Urz. cent.) / oprac. H. Lulewicz, A. Rachuba. Kórnik, 1994. S. 44; Urzędnicy Wielkiego Księstwa Litewskiego. Spisy. T. 1: województwo wileńskie XIV-XVIII wiek / red. A. Rachuba. Warszawa, 2004. S. 197.

${ }^{63} \mathrm{KP} 1753 . \mathrm{Nr}$ 871. Z Wilna. 2.V.1753.

${ }^{64}$ Вона відбулася 7.V.1753 р. Див.: Deputaci... S. 235.

${ }^{65}$ Він був номінований 23 жовтня 1752 р. 8 жовтня 1762 р. став воєводою віленським. Див.: Urz. cent. S. 100.

${ }^{66} \mathrm{KP} 1753 . \mathrm{Nr} 871 . \mathrm{Z}$ Wilna. 2.V.1753.

${ }^{67}$ Ibidem.

${ }^{68}$ Effectus (лат.) - ефекти.

69 Ex principiis dioptricis, catoptricis, hydrostaticis (лат.) - від тверджень діоптрики (галузь оптики, що займається вивченням явищ заломлення світла, і насамперед - через лінзу), катоптрики (займається явищами світловоду і оптичних систем, які створюють певну картину у випадку використання дзеркал; катодична система також називається катоптером); гідростатики (галузь механіки, яка займається вивченням рідин у стані спокою).

${ }^{70}$ Praeparatoria (лат.) - приготування. 
${ }^{71}$ Observatorii astronomii (лат.) - астрономічної обсерваторії. Її збудував Томаш Жебровський. Див.: EWOJ. S. 741.

${ }_{72}$ Facultati mathematicae (лат.) - кафедрі математики.

${ }^{73}$ Thelescopium gregorianum (лат.) - телескоп грегоріанський. Йдеться про різновид дзеркального телескопу, спроектований шотландським математиком і астрономом Джеймсом Грегорі в XVII ст. Збудував його вперше Роберт Гук в 1673 р.

${ }^{74}$ Raritates (лат.) - рідкісні інструменти. Див.: KP 1753. Nr 871. Z Wilna. 2.V.1753. Факт дарування телескопу Академії зафіксовано в історії місцевого єзуїтського академічного колегіуму: “[...] His duo considerandis caelestibus tubi optici, alter 150 aureis emptus dono celsissimi Michaelis Radivilii S. R. I. Principis Exercituum M. D. L. Ducis Palatini Vilnensis, septuaginta aureis alter dono Illmi Coadiutoris Vilnensis Josephi Sapieha sunt additi”. Див.: ARSI. Lituania. Nr 50. K. 258v-259r. В діаріуші «Рибоньки» відсутня інформація про здійснену фундацію. Див.: Diariusz Michała Kazimierza Radziwiłła «Rybeńki» [1702-1762]. Archiwum Główne Akt Dawnych. Archiwum Radziwiłłów. Dz. VI. Sygn. II-80a (kopia). K. 1908-1911.

${ }^{75}$ Szklarska E. Puzynina z Ogińskich 1.v. Giełgudowa Elżbieta Magdalena (zm. 1767) // PSB. T. 29. Wrocław, 1986. S. 503.

${ }^{76}$ Варто додати, що в 1755 р. Пузина пожертвувала на астрономічну обсерваторію Віленської академії “певні суми”, а в 1766 р. (або - в 1767 р.) встановила віковічний запис на сумму 6 тис. зл., а ще 3 тис. зл. передала готівкою. Див.: Ibidem.

${ }^{77}$ Бальбіна 3 роду Воловичів 3 січня 1728 р. (?) вийшла заміж за Юзефа Францішка Паца, який 12 жовтня 1748 р. був номінований на жмудську каштелянію. Див.: Urzędnicy Wielkiego Księstwa Litewskiego. Spisy. T. 3: Księstwo żmudzkie XV-XVIIII wiek / red. A. Rachuba. Warszawa, 2015. S. 167.

${ }^{78}$ Анна 3 роду Ромерів 10 лютого 1732 р. стала дружиною Яна Хрептовича, який починаючи 3 1752 р. був каштеляном брестським. Див.: Ryżewski G. Ród Chreptowiczów herbu Odrowąż. Kraków, 2006. S. $151,158-159$.

${ }^{79}$ Нар. 10.VI.1736 - пом. 17.Х.1753. Це була єдина дочка Анни (з роду Ромерів) і Яна Хрептовичів. Див.: Ibidem. S. 160.

${ }^{80}$ Анна з роду Потіїв 31748 р. була дружиною Юзефа Скумін Тишкевича, який був номінований на тивуна віленського в 1729 р. (?). Див.: Urz. wil. S. 93.

${ }_{81}$ Регіна 3 роду Войнів 25 січня 1728 р. вийшла заміж за Марціана Хрептовича, старосту вербельського. Див.: Ryżewski G. Ród Chreptowiczów... S. 141, 146.

82 Повний перелік дам, котрі були на демонстрації вмінь в Академії, див.: KP 1753. Nr 871. Z Wilna. 2.V.1753. 